\title{
The Synthesis of Naturally Occurring Vitamin $K$ and Vitamin $K$ Analogues
}

\author{
Alison M. Daines, Richard J. Payne, Mark E. Humphries, and Andrew D. Abell* \\ Department of Chemistry, University of Canterbury, Private Bag 4800, Christchurch, New Zealand
}

\begin{abstract}
The synthesis of vitamin $\mathrm{K}$ and its analogues has been an important goal since the biochemical roles of the $\mathrm{K}$ vitamins were elucidated. This review presents a detailed account of syntheses of natural $\mathrm{K}$ vitamins and analogues that contain side chain functionality.
\end{abstract}

\section{INTRODUCTION}

A number of life's key biochemical processes, including blood coagulation, bone metabolism and cell growth, are mediated by a family of natural products referred to as the $\mathrm{K}$ vitamins [1]. Much work has been carried out in recent times to elucidate the mechanisms by which these compounds elicit their activity, and a number of proteins that are vitamin $\mathrm{K}$-dependent have been identified in a variety of human tissues including the kidneys, spleen, lungs, uterus, placenta, thyroid, thymus, testes, and bones. As might be expected this commonality in function is reflected in a commonality in structure within this class of vitamin, i.e. they contain a naphthoquinone core, the substitution of which defines the exact $\mathrm{K}$ vitamin. For example, vitamin $\mathrm{K}_{1}$ (phylloquinone) $\mathbf{1}$ has a 3-phytyl substituent while vitamin $\mathrm{K}_{2}$ (menaquinone) 2 contains repeating unsaturated isoprene units at the $\mathbf{3}$ position. The menaquinones may be denoted as MK-n, where $\mathrm{n}$ is the number of repeating isoprene units (see Figure 1 ). The other form of vitamin $\mathrm{K}$ commonly encountered is 2methyl-1,4-naphthoquinone (vitamin $\mathrm{K}_{3}$ or menadione) 3 which lacks substitution at the $\mathbf{3}$ position. Although biologically active in vivo this compound is not found in nature.
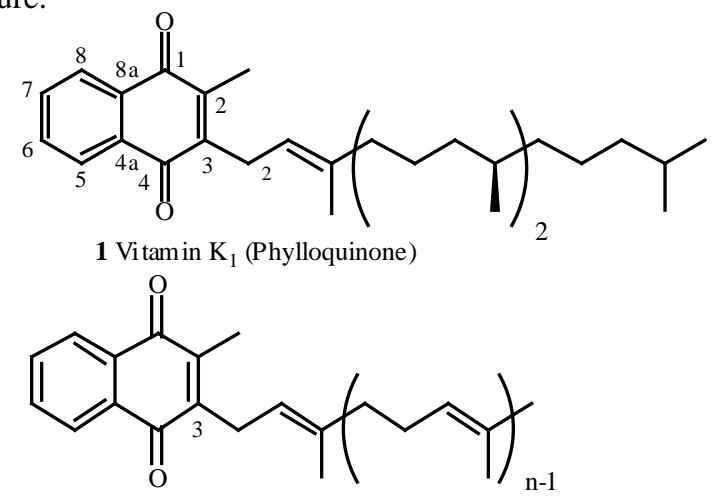

2 Vitamin $\mathrm{K}_{2}$ (Menaquinone)

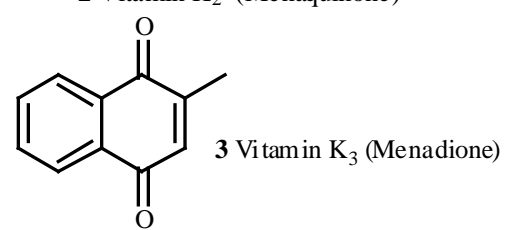

Fig. (1).

\footnotetext{
*Address correspondence to this author at the Department of Chemistry, University of Canterbury, Private Bag 4800, Christchurch, New Zealand; Tel: + 63 - 3 - 3642818; Fax: + $64-3$ - 3642110; E-mail: a.abell@chem.canterbury.ac.nz
}

The process of blood coagulation has been particularly well studied and the central role of vitamin $\mathrm{K}$ in this process has been elucidated [1]. It is now well documented that vitamin $\mathrm{K}$ is essential for the proper formation of prothrombin, the inactive precursor of thrombin - the enzyme that converts fibrinogen of blood plasma into fibrin that results in blood clots. This biochemical process is itself mediated by the carboxylation of specific glutamic acid (Glu) residues to $\gamma$-carboxyglutamic acid (Gla) residues in prothrombin in what is referred to as the vitamin K cycle [2]. The resulting vitamin K-dependent post-translational modification of Glu residues enables the protein to chelate calcium ions, and in the case of blood coagulation, this calcium ion is then able to form ion bridges to the phosphate head groups at the phospholipid membrane surfaces of blood platelets and endothelial cells [3]. The introduction of a Gla carboxyl group is also believed to confer structural changes to the protein as a result of calcium ion mediated Gla-Gla cross-linking [3].

Vitamin $\mathrm{K}$ has also been implicated in a number of other important physiological processes including early skeletal development maintenance of bone [2,4], cellular growth [5]. In association with its role in cell proliferation, vitamin $\mathrm{K}$ has also been shown to inhibit the growth of several tumour cell lines [6]. It is clear that the vitamin $\mathrm{K}$ family is of major importance to life as we know it and as such a good deal of effort has gone into developing general and efficient methods for the preparation of the $\mathrm{K}$ vitamins. This work is reviewed here for the first time. In addition, these methods have been extended to allow preparation of analogues of the $\mathrm{K}$ vitamins to help study these and related processes.

\section{SYNTHESIS OF NATURALLY OCCURRING K VITAMINS}

As vitamin $\mathrm{K}$ is not synthesised by higher animals it is necessary to obtain the required daily allowance through dietary sources. In nature the $\mathrm{K}$ vitamins are synthesised via the shikimic acid pathway, which is also utilised in the production of the aromatic amino acids [7]. The various prenyl side chains are synthesised via the terpene biosynthetic pathway before incorporation into the final compound [8]. Vitamin $\mathrm{K}_{1}$ is synthesised by plants and is found at significant levels in green leafy vegetables, certain legumes and some vegetable oils, such as rapeseed and soyabean oil [9]. Most fish, skeletal meats, cereals, and beverages also contain low but measurable amounts of vitamin $\mathrm{K}_{1}$ [9]. Vitamin $\mathrm{K}_{2}$ is predominantly synthesised by anaerobic bacteria including many species that inhabit the 


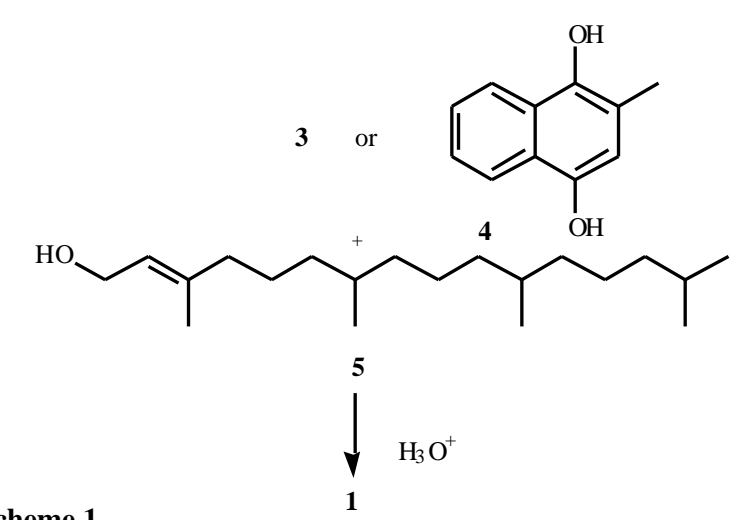

Scheme 1.<smiles>COc1cc(C)c(OC)c2ccccc12</smiles><smiles>CC(=O)Oc1cc(C)c2ccccc2c1OC(C)=O</smiles><smiles>COC1(OC)C=C(C)C(OC)(OC)c2ccccc21</smiles>

8

Fig. (2).

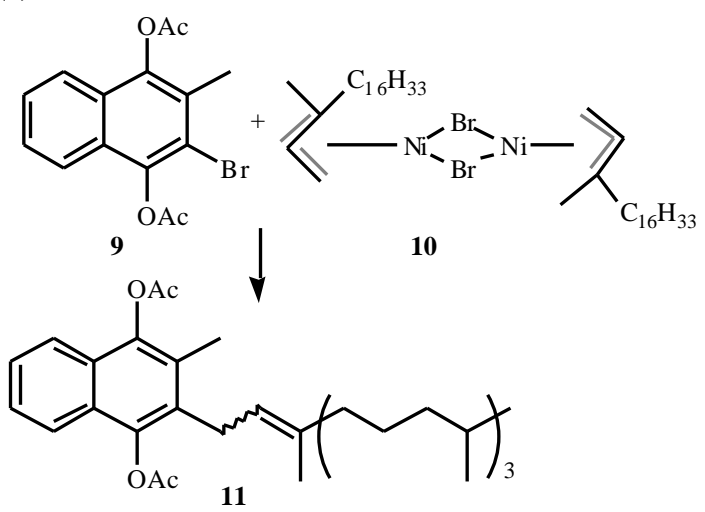

Scheme 2.

lining of the gut. The major forms of vitamin $\mathrm{K}_{2}$ from this source are MK-10 and MK-11 produced by the bacteroides, MK-8 from enterobacteria, MK-7 from veillonella $s p$ and MK-6 from Eubacterium lentum [9]. Vitamin $\mathrm{K}_{2}$ is also available through the diet from animal livers and fermented foods, including cheeses [9].

Another potential source of vitamin $\mathrm{K}$ is via dihydrovitamin $\mathrm{K}_{1}$, which is produced when vegetable oils are hydrogenated. Foods prepared using hydrogenated vegetable oils have shown significant quantities of dihydrovitamin $\mathrm{K}_{1}[10]$ and after consumption of such foods, dihydrovitamin $\mathrm{K}_{1}$ has been detected in human plasma, but its bioavailability is unknown [10]. It is estimated that in America dihydrovitamin $\mathrm{K}_{1}$ may account for up to $30 \%$ of the daily vitamin $\mathrm{K}$ intake, so this may become very important in assessing vitamin $\mathrm{K}$ status [10].

The first reported laboratory syntheses of vitamin $\mathrm{K}_{1}$ came independently from the laboratories of Fieser, [11] Binkley, [12] and Almquist / Klose [13] in 1939. Here, condensation of either, menadione $\mathbf{3}$ or 2-methyl-1,4naphthohydroquinone $\mathbf{4}$, with natural phytol $\mathbf{5}$ in the presence of oxalic acid or zinc dust in acetic acid, respectively, gave vitamin $\mathrm{K}_{1}$ (Scheme 1). Purification of the final product proved difficult and yields were low using

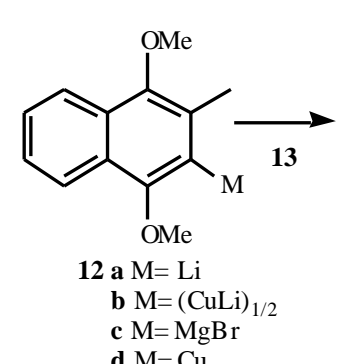<smiles>COc1c(C)c(CC=C(C)C)c(OC)c2ccccc12</smiles>

14 d $\mathrm{M}=\mathrm{Cu}$ $\downarrow \mathrm{AgO}, \mathrm{H}^{+}$

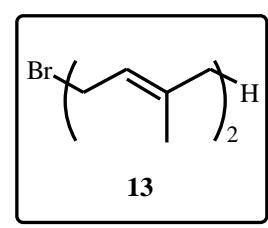<smiles>CC(C)=CCC1=C(C)C(=O)c2ccccc2C1=O</smiles>

Scheme 3.

these methods, with the formation of the chromanol (undefined cyclic isomers of the corresponding hydroquinones) proving a major problem.

These early syntheses were based upon Friedel-Craft alkylations for side chain coupling, which led to mixtures of isomers at the $\Delta^{2}$ position [11-13]. For example, the conventional Friedel-Crafts coupling of natural $E$-phytol to 2-methyl-1,4-naphthohydroquinone gave, after oxidation, a mixture containing approximately 90\% E-phylloquinone (isomerisation was occurring during the coupling process). An improvement on this method by Lindlar [14] using menadiol 1-benzoate as the starting material, and $\mathrm{BF}_{3} \cdot \mathrm{Et}_{2} \mathrm{O}$ as the catalyst, gave complete retention of stereochemistry in the side chain. This sequence also avoided chromanol cyclisation and competing C2-alkylation, however, its use remains limited by the inherent instability of the allylic alcohol to the acidic reaction conditions [15].

The majority of the more recent syntheses involve coupling a side chain to a suitably protected quinone core, the nature of the protection used being influenced by the nature of the subsequent chemistry and/or the deprotection methods involved. 1,4-Dimethoxynaphthalene $\mathbf{6}, \quad 1,4-$ diacetoxynaphthalene $\mathbf{7}$, and quinone bisketals 8 have all proven to be popular building blocks due to their ease of deprotection by oxidation, base or acid respectively.

The advent of transition metals in organic synthesis has greatly advanced the efficiency of coupling procedures employed for the synthesis of $\mathrm{K}$ vitamins. Initial reports employed allyl nickel complexes, [16] for example 2-bromo3-methyl-1,4-diacetoxynaphthalene 9 reacts with $E$ phytylnickel complex $\mathbf{1 0}$ to afford the acetyl protected vitamin $\mathrm{K}_{1} 11$ (Scheme 2). The $Z / E$ ratio of the products obtained was found to vary greatly with reaction solvent; $N$ methylpyrrolidone giving the most desirable results, a 8:2 ratio in favour of the $E$ isomer ( $75 \%$ combined yield). Vitamin $\mathrm{K}_{2}$ was synthesised in an analogous manner in $85 \%$ yield and in a ratio of 7:3 favouring of the $E$ isomer. The $Z / E$ ratio was increased to $87: 13$, in this example, by low temperature recrystallisation.

Snyder and Rappaport reported a synthesis of a series of menaquinones from a 2-metallo-3-methyl-1,4-dimethoxynaphthalene (12) and a suitable aldehyde or alkyl halide (Scheme 3) [17]. Of the metallonaphthalenes investigated, 
<smiles>CC(C)=CCCC1=C(C)C(=O)c2ccccc2C(=O)C1=C(C)C(C)(C)C</smiles>

Scheme 4.

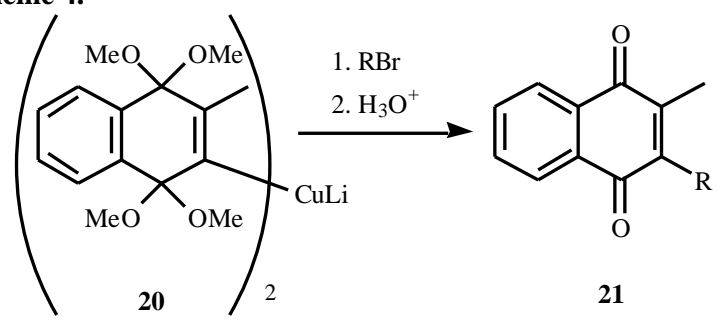

Scheme 5.

Grignard reagents proved the most reliable, giving excellent retention of the $E$ configuration $(98-99 \%)$. Coupling the Grignard reagent of 2-bromo-3-methyl-1,4dimethoxynaphthalene (12c) with geranylbromide (13) gave MK-2 in $80 \%$, while solanesyl bromide afforded MK-9 in 73\% yield. In both cases 2-bromo-3-methyl-1,4dimethoxynaphthalene was observed as a contaminating by product.

Evans and Hoffman published a regiospecific isoprenylation of benzo- and naphthoquinones as a route to the vitamin $\mathrm{K}$ family [18]. Cyanide-catalysed addition of trimethylsilyl cyanide (TMSCN) to 2-methoxy-3-methyl-1,4naphthoquinone gave the protected quinone 16. Quinone $\mathbf{1 6}$ then underwent $\mathrm{C} 1$ carbonyl addition with prenyl magnesium bromide 17 followed by a Cope rearrangement to the protected MK-1 18. Deprotection with $\mathrm{AgF}$ afforded the desired quinone 19 in $71 \%$ yield (Scheme 4).

Organocuprates have been used for the synthesis of the $\mathrm{K}$ vitamins. Chenard et al. [19] prepared menaquinone and phylloquinone from cuprates of quinone bisketals with allyl halides. The cuprate was itself prepared by metalation of the corresponding bromide. High yields and good stereoselectivity at the $\Delta^{2}$ position of the $\mathrm{K}$ vitamin product 21 were obtained (Scheme 5). The cuprate activity is substrate dependent with two alkyl groups being transferred with groups such as allyl bromide and one group being transferred with bulkier substrates such as benzyl chloride, cyclohexanecarbonyl acid chloride, and benzyl bromide [19]. Syper et al. [20] also utilised cuprate chemistry in the coupling of prenyl bromide and geranyl bromide to 2-bromo3-methyl-1,4-dimethoxynaphthalene to give the protected forms of MK-1 and MK-2 in $68 \%$ and $78 \%$ respectively. A method for the preparation of MK-4 was also reported by Garcias et al. [21] in 1994. This method involves coupling 2bromo-3-methyl-1,4-dimethoxynaphthalene with allylic

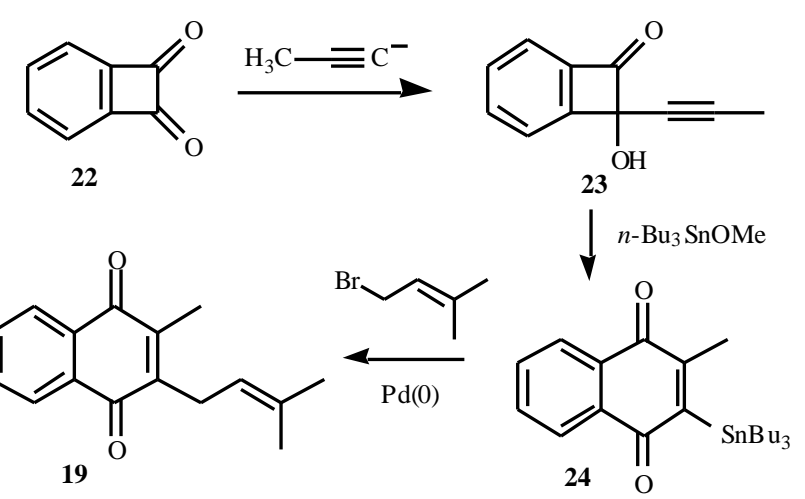

Scheme 6 .<smiles>C=CCC1=C(C)C(=O)c2ccccc2C1=O</smiles>

Scheme 7.

aldehydes using $n \mathrm{BuLi}$ to give the corresponding benzylic alcohol. Removal of the hydroxyl group under Birch conditions was shown to proceed with complete retention of $\Delta^{2}$ stereochemistry. A final oxidative deprotection of the quinone, gave MK-1 and MK-3 in 35\% and 30\% yield respectively.

Up until the early 1990's the majority of syntheses of K vitamins involved either Grignard reagents, organolithiums or organocuprates as discussed above. These methods required the use of protected quinones to suppress competing quinone reduction. The introduction of softer nucleophiles allowed direct allylation of the quinone nucleus without the need for protection. This allowed allylsilanes and allylstannanes to be used for direct allylation of unprotected quinones. For example, MK-1 19 has been synthesised from stannylquinones which are themselves derived from alkynylcyclobutenones [22]. Addition of a propyne nucleophile to dione 22 followed by stannylation with $n$ $\mathrm{Bu}_{3} \mathrm{SnOMe}$ and subsequent Liebeskind-Moore rearrangement afforded the stannylquinone $\mathbf{2 4}$ in $49 \%$ yield over the 2 steps. A final Stille coupling with prenyl bromide gave MK-1 in 90\% yield (Scheme 6).

Allylstannanes have also been photochemically coupled to benzo- and naphthoquinones as outlined in Scheme 7 [23a]. The reaction, performed under $315 \mathrm{~nm}$ light, in benzene or acetonitrile, gave a mixture of products from which 2-allyl-3-methyl-1,4-naphthoquinone 25 crystallised in $15-40 \%$ yield. This approach avoids the use of more traditional Lewis acid catalysis for substrate activation. A related route to vitamin $\mathrm{K}$ based on a photochemicalmediated radical coupling of a geranyl organotellurium species to 3 was reported in 2002 (Scheme 8) [23b]. Thus, geranyl tolyl telluride 26 (73:27 mixture of $E$ and $Z$ isomers, prepared from the corresponding bromide on treatment with $\mathrm{SmI}_{2}$ and ditolyl ditelluride) was coupled to 3 to give MK-2 (27) in $73 \%$ yield (7:3 $E$ to $Z$ ).

In 1995 a synthesis of MK-1 was reported by Hagiwara et al. [24] based upon a regioselective allylation of 2-bromo3-methyl-1,4-naphthoquinone $\mathbf{2 8}$ with (3-methyl-2- 
<smiles>CCCCCCCCCCCCCCCCC=C(C)CCC=C(C)C</smiles>

Scheme 8.<smiles>CC(C)=CCC1=C(C)C(=O)c2ccccc2C1=O</smiles><smiles>[R]C([R])=CC[SiH2]CC1(C)CC(=O)c2ccccc2C1=O</smiles>

Scheme 9.

butenyl)trifluorosilane in formamide at $80^{\circ} \mathrm{C}$ (Scheme 9). By contrast, the alkylation of the non-halogenated 2-methyl1,4-naphthoquinone $\mathbf{3}$ occurred at the substituted C2 carbon to give 29. An allylindium $\mathbf{3 0}$ has also been used to prepare simple menaquinones from 2-bromo-3-methyl-1,4-naphthoquinone with the indium transferring two of the three available allyl groups from the complex [25]. Prenylindium 30 and 28 react to give the MK-1 vitamin in 67\% yield (see Scheme 10). The authors postulate that the reaction proceeds by addition to the carbonyl group followed by a $[3,3]$ sigmatropic rearrangement of the prenyl group, rather than the direct substitution at the 2-position of the ring. MK-1 has also been prepared via the coupling of 2-methyl-1,4naphthoquinone to prenyl units using a lead bromide and aluminium powder catalyst. This catalyst allows the coupling to be carried out at room temperature under conditions that are not strictly anhydrous. The mono-prenylated product MK-1 was obtained exclusively in 50\% yield [26].

An alternative approach to the $\mathrm{K}$ vitamins involves the stepwise elongation of a suitable short side chain analogue. This methodology has been used to prepare natural phylloquinone (Vitamin $\mathrm{K}_{1}$ ) as a mixture of stereoisomers [27]. The addition of the Grignard reagent derived from 2bromo-3-methyl-1,4-dimethoxynaphthalene 31, to isoprene epoxide 32, gave the short chain alcohol derivative 33 . Conversion of $\mathbf{3 3}$ into the corresponding acetate 34, followed by addition of a second Grignard reagent gave vitamin $\mathrm{K}_{1}$ (Scheme 11).

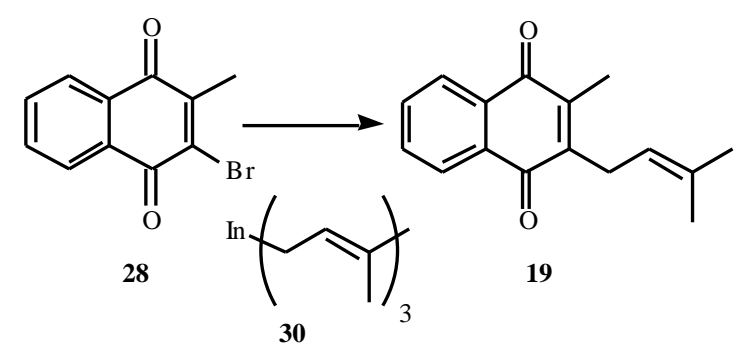

Scheme 10.

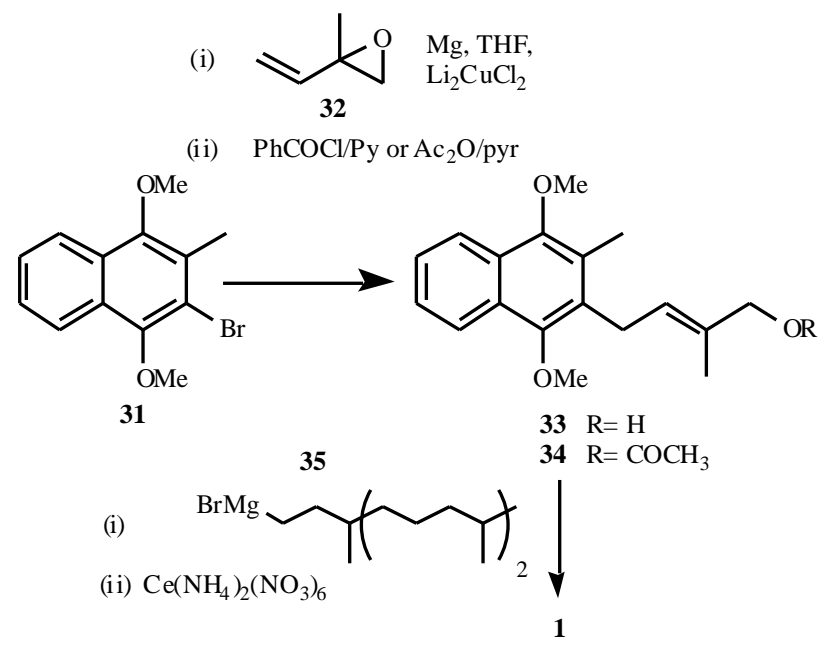

Scheme 11.

More recently, $\mathrm{Ni}(0)$ catalysts have been used by Lipshutz to extend the side chains of simple derivatives to provide a convenient synthesis of phylloquinone and menaquinones (Scheme 12) [28a]. Here, chloromethylated quinone 36 (prepared either, by direct chloromethylation of the quinone or from oxidation of corresponding benzylic chloride) was reacted with the trimethylaluminium functionalised side-chains $\mathbf{3 7 a}$ and $\mathbf{3 8}$ in the presence of 0.5 mol\% $\mathrm{Ni}(0)$ to give racemic phylloquinone $\mathbf{1}$ in $88 \%$ yield and MK-3 39 in 93\% yield, respectively [28a]. The chloromethyl quinone $\mathbf{3 6}$ has also been used to prepare vitamin $\mathrm{K}$ via direct $\mathrm{Pd}$-catalysed alkenylation with a alkenylalane derived from $\mathbf{3 7 b}$, Scheme 12 [28b].

There are a few other isolated reports on the synthesis of the vitamin $\mathrm{K}$ family. For example, $\beta$-cyclodextrin has been shown to catalyse a key coupling step in the synthesis of vitamin $\mathrm{K}_{1}, \mathrm{~K}_{2}$, and analogues [29]. The reaction of 2methyl-1,4-naphthoquinone and a respective bromide using $\beta$-cyclodextrin in phosphate buffer containing $30 \%$ methanol gave the $\mathrm{K}$ vitamin in yields ranging from $40-60 \%$. It was postulated that cyclodextrin acts as a ligase and/or oxygenase, i.e. a 'vitamin $\mathrm{K}$ synthase', in this reaction.

In another isolated report, natural phylloquinone $\mathbf{1}$ has been synthesised by an $O$-alkylation of the menadiol monoactetate $\mathbf{4 0}$ giving ether $\mathbf{4 1}$ which is followed by a Lewis acid catalysed rearrangement [27]. The intramolecular rearrangement of $\mathbf{4 1}$ occurs under mild reaction conditions and low catalyst loading to give a high $(E)$-selectivity in the double bond formation (Scheme 13). This approach has received little attention. 

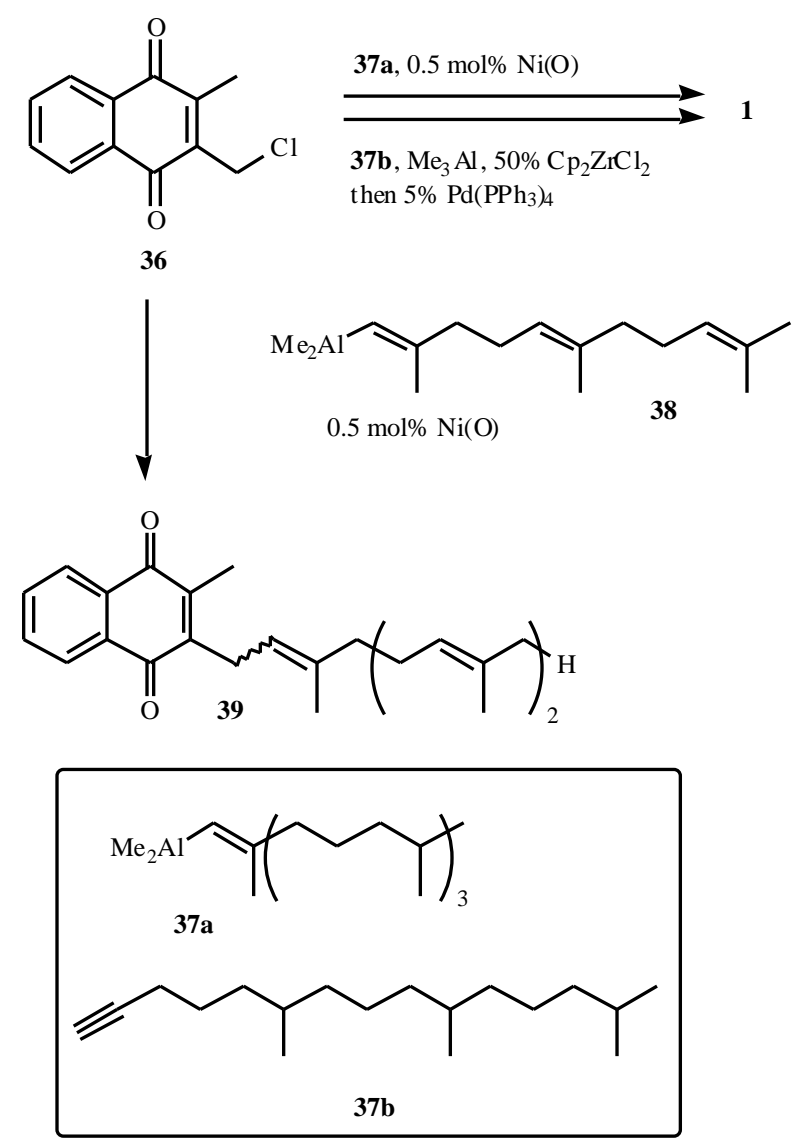

Scheme 12.

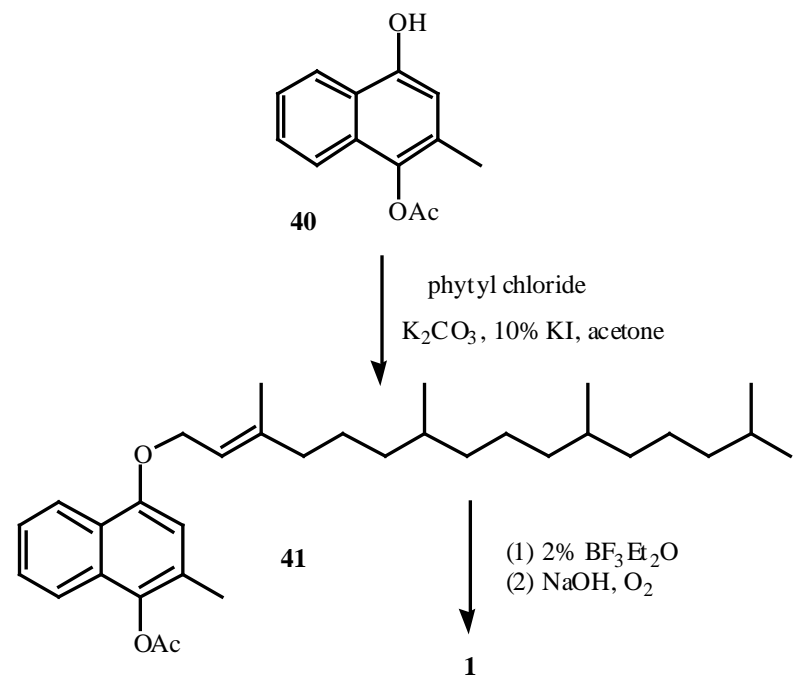

Scheme 13.

In 1995 Tso et al. [30] published a novel one-pot procedure to $\mathrm{K}$ vitamins that is conceptually quite different to those already discussed (Scheme 14). Treatment of 3substituted isobenzofuranone $\mathbf{4 3}$ with base generated a quinone methide which underwent a [4+2] cycloaddition with the alkyl phenyl-sulfone 42. Elimination of the sulfone from intermediate $44 \mathrm{in}$ situ then gave phylloquinone in $61 \%$ yield. MK-1, MK-2 and MK-9 were also prepared in this manner in $60 \%, 63 \%$, and $64 \%$ yield, respectively [30].<smiles>[R]/C(=C/C)S(=O)(=O)Oc1ccccc1</smiles>

42<smiles>[R]C1=C(C)C(=O)c2ccccc2C1=O</smiles>

Scheme 14.<smiles>CC(C)OCCC(C)C(C)C</smiles><smiles>CC1=C(CCC(C)C(=O)O)C(=O)c2ccccc2C1=O</smiles><smiles>CC(=O)Oc1c(C)cc(O)c2ccccc12</smiles>

40

49<smiles>COC(=O)CC/C(C)=C/CO</smiles>

Scheme 15.

Synthesis of vitamin $K$ analogues with side chain functionality

The development of methods for the synthesis of analogues of vitamin $\mathrm{K}$ have also received a good deal of attention with a view to understanding structure activity relationships (SAR) within this family of compounds. In addition, vitamin $\mathrm{K}$ analogues are of interest as potential inhibitors of vitamin $\mathrm{K}$ dependant carboxylase and vitamin $\mathrm{K}$ epoxide reductase [31,32]. They have also been used to investigate and characterise possible metabolites of the $\mathrm{K}$ vitamins.

The stereochemistry at the side chain alkene of vitamin $\mathrm{K}_{1}$ is known to be essential for biological activity [33]. The natural form of vitamin $\mathrm{K}_{1}$ and the MK's has a $E$ configuration, and the synthetic $Z$ isomer exhibits little or no activity $[33,34]$. Of the menaquinone series MK-3 to MK-5 appear to be the most biologically active in vivo. [7]. The longer chain menaquinones have been shown to be highly active in vitro but they may be less well absorbed, due to 


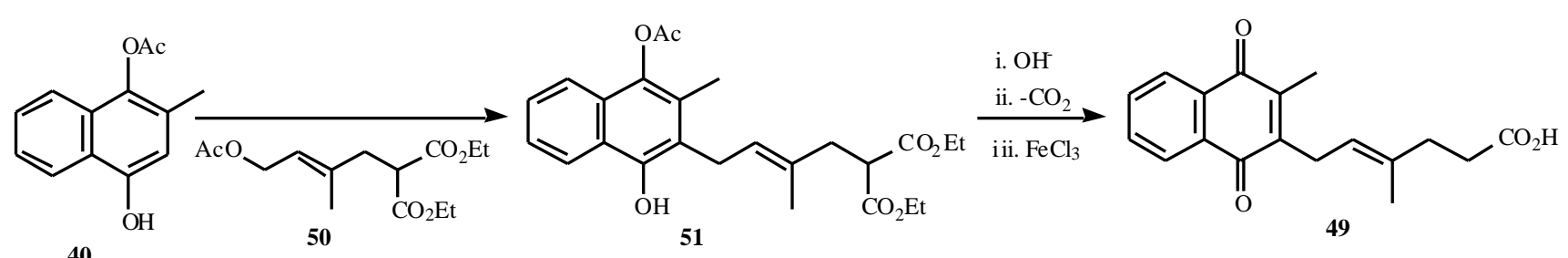

40<smiles>CC1=C(C/C=C(\C)CC(C(=O)O)C(=O)O)C(=O)c2ccccc2C1=O</smiles><smiles>CCOC(=O)C(CCO)CC(C)CCc1c(C)c(OC(C)=O)c2ccccc2c1O</smiles><smiles>CC1=C(CCC(C)CCC(=O)O)C(=O)c2ccccc2C1=O</smiles>

Scheme 16.

increased hydrophobicity, leading to a lower biological activity [35]. The unnatural vitamin $\mathrm{K}_{3}$ has also been shown to exhibit biological activity but it is unknown if this is alkylated in vivo to produce an active compound [7]. An investigation of the biological activity of a series of analogues of vitamin $\mathrm{K}$ has also provided some structure activity information on these compounds [7]. 2-Methyl-4amino-1-naphthol and 2-methyl-1-naphthol were shown to have biological activity similar to menadione [7]. Diphosphate, disulfate, diacetate, and dibenzoate forms of the reduced $\mathrm{K}$ series exhibited full biological activity, [7] possibly due to the fact that it is the reduced form of vitamin $\mathrm{K}$ that is biologically active. A methyl group at the 2 position is essential for activity, with the 2-ethyl and other alkylated derivatives showing no activity $[33,34]$. In addition to this the 2-chloro and 2-bromo derivatives are both potent antagonists of vitamin K [7]. 2-Phytyl-1,4-naphthoquinone has been shown to exhibit biological activity, however it is thought to be methylated in vivo to vitamin $\mathrm{K}_{1}$ [7]. Saturation of the double bond of vitamin $\mathrm{K}_{1}$ reduces activity considerably, but the compound still exhibits more activity than branched chain $K_{1}$ analogues [7]. Finally, alteration of the naphthoquinone core in any manner also leads to a loss in biological activity [7].

A wide variety of analogues of vitamin $K$ have been synthesised including substituted vitamin $\mathrm{K}$ epoxides, [31,32] methylated naphthoquinones, [36] and side-chain functionalised vitamin $\mathrm{K}$ analogues [37-48] since the early efforts in the mid 1970's. In this review we are concerned solely with the last class of analogue since the chemistry involved in their synthesis correlates with that already discussed.

One of the earliest syntheses of vitamin $\mathrm{K}$ analogues (see 47 and 49, Scheme 15) was reported by Watanabe et al. [39]. Reaction of the radical derived by thermolysis of peroxide $\mathbf{4 6}$

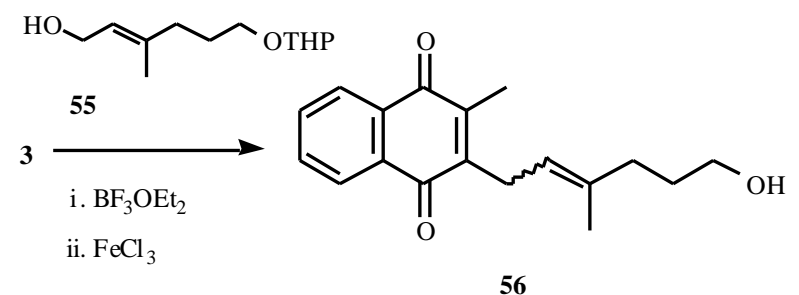

\section{Scheme 17.}

with 2-methyl-1,4-napthoquinone $\mathbf{3}$, followed by ester hydrolysis, gave the vitamin $\mathrm{K}$ analogue 47 in $50 \%$ yield based on the peroxide. However, it is important to note that the starting peroxide was prepared in a three-step synthesis in only $5 \%$ yield. The authors also reported condensation of 1-acetoxy-4-hydroxy-2-methylnaphthalene $\mathbf{4 0}$ with methyl 6-hydroxy-4-methylhex-4-enoate 48 to give 49 in $42 \%$ yield to give a 3:1 mixture of $Z: E$ isomers.

Watanabe also reported [40] a related synthetic approach to carboxylated side-chain vitamin $\mathrm{K}$ analogues (Scheme 16). Condensation of monoacetate $\mathbf{4 0}$ and diester $\mathbf{5 0}$ in the presence of $\mathrm{BF}_{3} \cdot \mathrm{Et}_{2} \mathrm{O}$ afforded the malonate intermediate $\mathbf{5 1}$ in $66 \%$ yield. As before, this synthesis is hindered by the multi-step preparation of compound 50. Intermediate 51 however, proved to be a useful synthetic intermediate being able to be hydrolysed to the unsaturated diacid $\mathbf{5 2}$, decarboxylated to the unsaturated mono acid 49 or hydrogenated and hydrolysed to the saturated acid 54. In a related sequence (Scheme 17) the alcohol derivative $\mathbf{5 6}$ was prepared from the 2-methyl-1,4-naphthoquinol 3 by coupling the monoprotected diol $\mathbf{5 5}$ to the quinol in the presence of $\mathrm{BF}_{3} \cdot \mathrm{Et}_{2} \mathrm{O}$. Deprotection and oxidation afforded the analogue 56 in $29 \%$ yield as a mixture of $Z / E$ isomers. More recently, saturated naphthoquinone acids 57 (c.f. 54 in Scheme 17) have been used to prepare a library of 1,4-naphthoquinone 
<smiles>[R12]C(=O)CCC1=C(C)C(=O)c2ccccc2C(=O)C1=CCC(=O)NCC1=C(C)C(=O)c2ccccc2C1=O</smiles>

Scheme 18.

amides 59 which were screened for inhibitory activity against Trypanothione Reductase from Trypanosoma cruzi, the causal agent of Chagas disease, Scheme 18 [49].

A series of vitamin $\mathrm{K}$ analogues bearing an alcohol functionality have been prepared as outlined in Scheme 19 [38]. Condensation of 2-methyl-1,4-naphthohydroquinone 4 with cinnamoyl alcohol followed by oxidation with ferric chloride afforded the phenylpropenylquinone 60. Reductive acetylation then gave the acetyl protected hydroquinone 61 which was oxidatively cleaved with $\mathrm{OsO}_{4} / \mathrm{NaIO}_{4}$ to give the corresponding aldehyde $\mathbf{6 2}$. Wittig chemistry was then used to extended the side chain to give $\mathbf{6 3}$ which was either, reduced with lithium aluminium hydride to give alcohol $\mathbf{6 4}$,

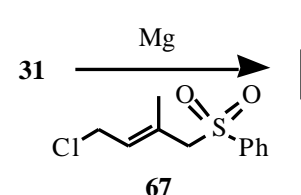<smiles>COc1c(C)c(C/C=C(\C)CS(=O)(=O)c2ccccc2)c(OC)c2ccccc12</smiles>

68

Scheme 20.

or hydrolysed and oxidised to give a mixture of acids $\mathbf{6 5}$ and 66 [38].

An efficient synthesis of sulfone functionalised analogues of vitamin $\mathrm{K}$ has been reported by Fujita et al. (Scheme 20) [41]. This was achieved via the Grignard coupling of 2-bromo-3-methyl-1,4-dimethoxynaphthalene 31 with E-4-chloro-2-methyl-1-phenylsulfonyl-2-butene 67 to give sulfone analogue $\mathbf{6 8}$ in $82 \%$ yield. Sulfone 67 was conveniently obtained from the reaction of isoprene with benzenesulfonyl chloride in the presence of copper chloride/TEA hydrochloride as catalyst.

An important study by Terao et al. [42] reports the synthesis of a series of quinone derivatives that contain modified polyprenyl side chains (Scheme 21). The regiospecific modification of the terminal prenyl group of ubiquinone, menaquinone or tocoquinone side chains gave a convenient synthesis of quinone acids, quinone amides, quinone alcohols and quinone methylketones. In this work, isomerisation of the epoxide $\mathbf{7 0}$ gave the allylic alcohol $\mathbf{7 1}$ which underwent a Claisen rearrangement (irrespective of the number $n$ of prenyl units in the side chain) to the ester 72. This was followed by either, deprotection and oxidation to give the acid $\mathbf{7 3}$, or reduction to give the alcohol $\mathbf{7 4}$. The result of the sequence is to increase the length of the sidechain by two carbon units as well as introducing terminal functionality.<smiles>CCOC(=O)CO</smiles><smiles>CC(=O)Oc1c(C)c(C/C=C/c2ccccc2)c(OC(C)=O)c2ccccc12</smiles><smiles>COc1c(C)c(CC=O)c(OC(C)=O)c2ccccc12</smiles><smiles></smiles><smiles>CC1=C(C/C=C(\C)C(=O)O)C(=O)c2ccccc2C1=O</smiles>

65<smiles>CC1=C(CC(O)C(C)C(=O)O)C(=O)c2ccccc2C1=O</smiles>

66
64

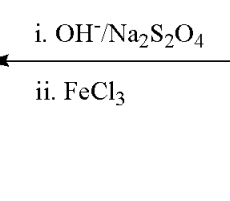<smiles>CCOC(=O)/C(C)=C/Cc1c(C)c(OC(C)=O)c2ccccc2c1OC(C)=O</smiles>

63<smiles>CC1=C(C/C=C(\C)CO)C(=O)c2ccccc2C1=O</smiles>

Scheme 19. 


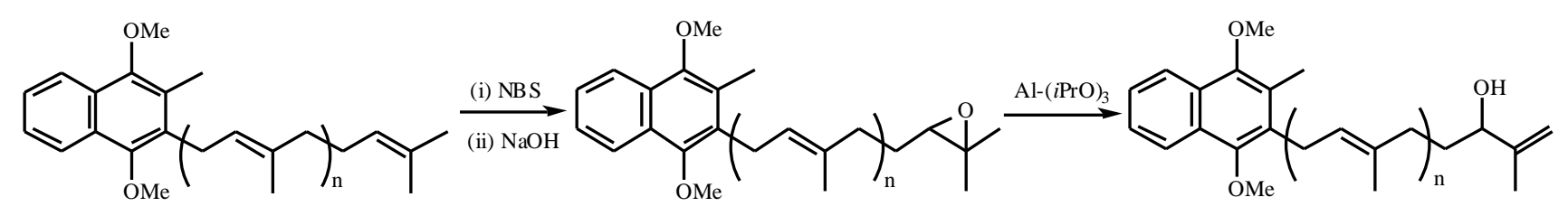

69<smiles>C=C1C(=O)c2ccccc2C(=O)C1=C(C)CCC(C)=CCC(C)=CCC(C)=CCC(=O)O</smiles><smiles>CC(=CCCCO)CC=C(C)CCCC(C)=C(C)C(=O)c1ccccc1C</smiles>

70<smiles>CCOC(=O)CC/C(C)=C/CC/C(C)=C/Cc1c(C)c(OC)c2ccccc2c1OC</smiles>

Scheme 21.<smiles>[R]C(=O)On1ccccc1=S</smiles><smiles>[R]C1=C(C)C(=O)c2ccccc2C1=O</smiles>

75

\section{Scheme 22.}

Work has been reported by Barton et al. on the synthesis of hindered quinones via radical reactions, Scheme 22 [43]. On photolysis with tungsten light, acyl derivatives of $N$ hydroxy-2-thiopyridone afford carbon radicals that readily add to 2-methylnaphthoquinone 3 . The resulting adducts then provide access to a number of hindered naphthoquinones including vitamin $\mathrm{K}$ based compounds $\mathbf{7 5}$ with side chain functionality such as phenyl, isopropyl, and carboxyethyl.

The synthesis of a deuterated analogue of vitamin $\mathrm{K}$ was published in 2002 by Payne and Abell, where a terminal carboxylic acid was incorporated into the structure to allow attachment to a protein via lysine side chain coupling (Scheme 23) [44]. The synthesis began with a reductive methylation of $\mathbf{3}$ using dimethyl sulfate and sodium dithionite in the presence of the phase-transfer catalyst, tetrabutylammonium iodide (TBAI), to give the methoxy protected napthoquinone 76. This was then brominated to afford the aryl bromide 77. The introduction of the C3 substituent was then achieved by a cuprate-mediated coupling of ethyl bromoacetate to a lithiated derivative of $\mathbf{7 7}$, to give $\mathbf{7 8}$. The ester $\mathbf{7 8}$ was then reduced with lithium aluminium deuteride to give the alcohol 79, labelled with deuterium at the 2-position of the hydroxyethyl group. Introduction of the side chain linker was achieved by reaction with succinic anhydride in the presence of dimethylaminopyridine (DMAP) to give the protected vitamin $\mathrm{K}$ analogue $\mathbf{8 0}$ in $45 \%$ yield. Finally, oxidative deprotection of $\mathbf{8 0}$ with ceric ammonium nitrate (CAN) afforded the desired vitamin $\mathrm{K}$ analogue $\mathbf{8 1}$ in $81 \%$ yield, which was then used in conjugation studies to lysozyme [44].

Finally, a number of thioalkyl vitamin $\mathrm{K}$ analogues have also been reported which show interesting medicinal properties, including antitumour activity $[45,46]$. The general synthetic scheme for production of these analogues involves the direct reaction of menadione with the respective thiol in a mixture of methanol and 2-propanol. A number of compounds of this type are currently under investigation as potential anticancer compounds $[47,48]$.

\section{CONCLUSION}

The vitamin $\mathrm{K}$ family of compounds play a central role in a number of biochemical processes that are fundamental to life. As such their synthesis has attracted a good deal of attention and the methods developed now provide access to non-natural analogues that are of medicinal interest. Early 


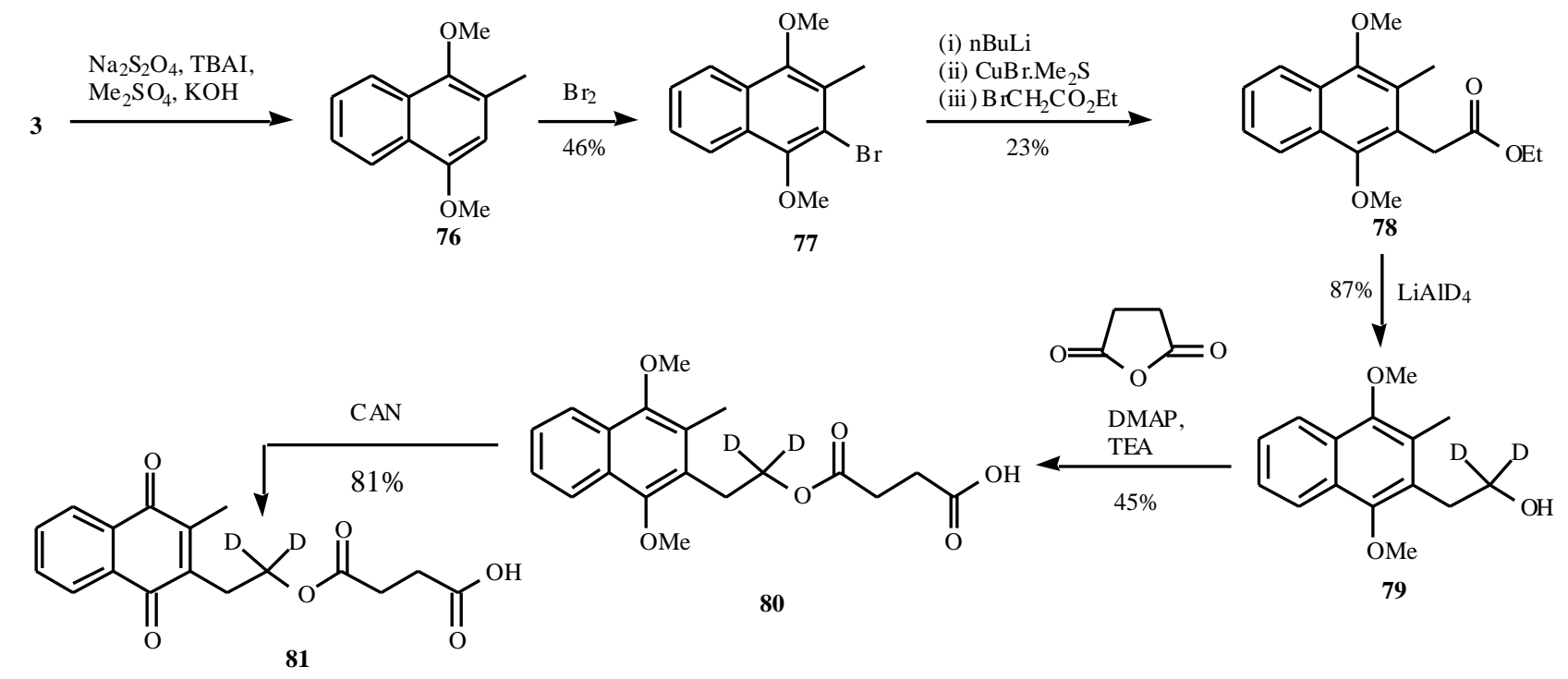

Scheme 23.

Friedel-Craft based syntheses suffered from problems of low yield and isomerisation of the side chain due to harsh reaction conditions employed. Much milder methods are now available that simplify the need for protection of the naphthoquinone core while being compatible with a range of functionality.

\section{REFERENCES:}

[1] Nelsestuen, G. L.; Shah, A. M.; Harvey, S. B. Vitamins and Hormones 2000, 58, 355.

[2] Dowd, P.; Ham, S. W.; Geib, S. J. J. Am. Chem. Soc. 1991, 113, 7734.

[3] Dowd, P.; Hershline, R.; Ham, S. W.; Naganathan, S. Science 1995, 269, 1684. Berkner, K. L.; Pudota, B. N. Proc. Natl. Acad. Sci. USA 1998, 95, 466. Houben, R. J. T. J.; Jin, D.; Stafford, D. W.; Proost, P.; Ebberink, R. H. M.; Vermeer, C.; Soute, B. A. M. Biochem. J. 1999, 341, 265.

[4] Vermeer, C.; Jie, K. S. G.; Knapen, M. H. J. Ann. Rev. Nutr. 1995, 15, 1. Shearer, M. J.; Bach, A.; Kohlmeier, M. J. Nutr. 1996, 126, 1181s. Shearer, M. J. Proc. Nutr. Soc. 1997, 56, 915.

[5] Nakano, T.; Kawamoto, K.; Kishino, J.; Nomura, K.; Higashino, K.; Arita, H. Biochem. J. 1997, 323, 387.

[6] Prasad, K. N.; Edwards-Prasad, J.; Sakamoto, A. Life Sci. 1981, 29 , 1387. Ngo, E. O.; Sun, T.-P.; Chang, J.-Y.; Wang, C.-C.; Chi, K.H.; Cheng, A.-L.; Nutter, L. M. Biochem. Pharm. 1991, 42, 1961. Ni, R.; Nishikawa, Y.; Carr, B. I. J. Biol. Chem. 1998, 273, 9906.

[7] Suttie, J. W. In Handbook of vitamins; Machlin, L. J., Ed.; Marcel Dekker Inc: New York, 1991, p 145-194.

[8] Begley, T. P.; Kinsland, C.; Taylor, S.; Tandon, M.; Nicewonger, R.; Wu, M.; Chiu, H.-J.; Kelleher, N.; Campobasso, N.; Zhang, Y. Topics Curr. Chem. 1998, 195, 93.

[9] Shearer, M. J. Lancet 1995, 345, 229.

[10] Booth, S. L.; Pennington, J. A. T.; Sadowski, J. A. Lipids 1996, 31, 715 .

[11] Fieser, L. F. J. Am. Chem. Soc. 1939, 61, 2559.

[12] Binkley, S. B.; Cheney, L. C.; Holcomb, W. F.; McKee, R. W.; Thayer, S. A.; MacCorquodale, D. W.; Doisy, E. A. J. Am. Chem. Soc. 1939, 61, 2558.

[13] Almquist, H. J.; Klose, A. A. J. Am. Chem. Soc. 1939, 61, 2557.

[14] Lindlar, H. Patent No. 320582, Switzerland, 1953.

[15] Stevens, K. L.; Jurd, L.; Manners, G. Tetrahedron 1972, 28, 1939.

[16] Sato, K.; Inoue, S.; Saito, K. J. Chem. Soc. Perkin Trans. 1 1973, 2289.

[17] Snyder, C. D.; Rappaport, H. J. Am. Chem. Soc. 1974, 96, 8046.
[18] Evans, D. A.; Hoffman, J. M. J. Am. Chem. Soc. 1976, 98, 1983.

[19] Chenard, B. L.; Manning, M. J.; Raynolds, P. W.; Swenton, J. S. J. Org. Chem. 1980, 45, 378.

[20] Syper, L.; Kloc, K.; Mlochowski, J. Tetrahedron 1980, 36, 123.

[21] Garcias, X.; Ballester, P.; Capo, M.; Saa, J. M. J. Org. Chem. 1994, 59, 5093.

[22] Liebeskind, L. S.; Foster, B. S. J. Am. Chem. Soc. 1990, 112, 8612.

[23] (a) Maruyama, K.; Imahori, H. Bull. Chem. Soc. Jpn. 1989, 62, 816.

(b) Yamago, S.; Hashidume, M.; Jun-ichi, Y. Tetrahedron 2002, 58,6805 .

[24] Hagiwara, E.; Hatanaka, Y.; Gohda, K.-I.; Hiyama, T. Tetrahedron Lett. 1995, 36, 2773.

[25] Araki, S.; Katsumura, N.; Butsgan, Y. J. Organomet. Chem. 1991, $415,7$.

[26] Khanna, R. N.; Singh, P. K. Synth. Commun. 1990, 20, 1743.

[27] Schmid, R.; Antoulas, S.; Ruttimann, A.; Schmid, M.; Vecchi, M.; Weiser, H. Helv. Chem. Acta 1990, 73, 1276.

[28] (a) Lipshutz, B. H.; Kim, S.-K.; Mollard, P.; Stevens, K. L. Tetrahedron 1998, 54, 1241 .

(b) Huo, S.; Negishi, E-I. Org. Lett. 2001, 3, 3253.

[29] Tabushi, I.; Yamamura, K.; Fujita, K.; Kawakubo, H. J. Am. Chem. Soc. 1979, 101, 1019.

[30] Tso, H.-H.; Chen, Y.-J. J. Chem. Res. (S) 1995, 104.

[31] Silverman, R. B.; Oliver, J. S. J. Med. Chem. 1989, 32, 2138.

[32] Ryall, R. P.; Nandi, D. L.; Silverman, R. B. J. Med. Chem. 1990, 33, 1791.

[33] Shearer, M. J. In Encyclopaedia of Food Science, Food Technology and Nutrition; Macrae, R., Robinson, R. K., Sadler, M. J., Eds.; Academic Press: London, 1993, p 4804.

[34] Suttie, J. W. Ann. Rev. Biochem. 1985, 54, 459.

[35] Suttie, J. W. Ann. Rev. Nutr. 1995, 15, 399.

[36] Schmid, R.; Goebel, F.; Warnecke, A.; Labahn, A. J. Chem. Soc. Perkins Trans. 2 1999, 1199.

[37] Masaki, Y.; Sakuma, K.; Kaji, K. Chem. Pharm. Bull. 1985, 33, 1930.

[38] Okamoto, K.; Watanabe, M.; Kawada, M.; Goto, G.; Ashida, Y.; Oda, K.; Yajima, A.; Imada, I.; Morimoto, H. Chem. Pharm. Bull. 1982, 30, 2797.

[39] Watanabe, M.; Kawada, M.; Nishikawa, M.; Imada, I.; Morimoto, H. Chem. Pharm. Bull. 1974, 22, 566.

[40] Watanabe, M.; Okamoto, K.; Imada, I.; Morimoto, H. Chem. Pharm. Bull. 1978, 26, 774. 
[41] Fujita, Y.; Ishiguro, M.; Onishi, T.; Nishida, T. Synthesis 1981, 469.

[42] Terao, S.; Shiraisi, M.; Kato, K.; Ohakawa, S.; Ashida, Y.; Maki, Y. J. Chem. Soc. Perkin Trans. 1 1982, 2909.

[43] Barton, D. H. R.; Sas, W. Tetrahedron 1990, 46, 3419.

[44] Payne, R. J.; Abell, A. D. Chem. N. Z. 2002, 66(1), 16.

[45] Nishikawa, Y.; Carr, B. I.; Wang, M.; Kar, S.; Finn, F.; Dowd, P.; Zheng, Z. B.; Kerns, J.; Naganathan, S. J. Biol. Chem. 1995, 270, 28304. Carr, B. I.; Wilcox, C. S.; Kerns, J. K. PCT Int. Appl. 2000, 08495.

[46] Kar, S.; Adachi, T.; Carr, B. I. J. Cell Phys. 2002, 190, 356.
[47] Ni, R.; Nishikawa, Y.; Carr, B. I. J. Biol. Chem., 1998, 273, 9906. Tamura, K.; Southwick, E. C.; Kerns, J.; Rosi, K.; Carr, B. I.; Wilcox, C.; Lazo, J. S. Cancer Research, 2000, 60, 1317. Wang, Z.; Nishikawa, Y.; Wang, M.; Carr, B. I. Journal of Hepatology 2002, 36, 85 .

[48] Chen, C.; Liu, Y.; Shia, K.; Tseng, H. Biorg. Med. Chem. Lett. 2002, 12, 2729.

[49] Salmon-Chemin, L.; Lemaire, A.; De Freitas, S.; Deprez, B.; Sergheraert, C.; Davioud-Charvet, E. Bioog. Med. Chem. Lett. 2000, 10,631 